\title{
Prescribing and formulating neonatal intravenous feeding solutions by microcomputer
}

\author{
P MACMAHON \\ Department of Paediatrics, Charing Cross Hospital, London
}

SUMMARY This paper describes a computer programme for a low cost microcomputer* designed to assist in the task of administering total parenteral nutrition to neonates: no knowledge of computers is necessary to operate the system. The programme displays recommended values for each of the total parenteral nutrition constituents that must be prescribed, based on detailed analysis of all the pertinent variables. The recommended values may be rejected but they do provide a useful prompt, especially for the more junior doctors. The programme includes a number of safeguards that protect against entering potentially dangerous values. As soon as the operator has completed the procedure of entering total parenteral nutrition requirements the calculations necessary to formulate a solution containing these are automatically performed. The print out contains this data plus instructions on the infusion rate and an analysis of the formulation's calorific content.

This system makes it easier to vary the quantity of individual total parenteral nutrition constituents and time has been saved which was previously wasted performing laborious calculations. One of the most important contributions has been the virtual elimination of errors in the complex task of prescribing and formulating total parenteral nutrition for sick neonates.

Critically ill preterm infants frequently require total parenteral nutrition. The amount of each component (total fluid volume, electrolytes, dextrose, protein, fat, etc) that should be given varies each day, especially in the first week of life. Once the clinical state of the infant has been reviewed together with that day's laboratory results, adjustments to the basic total parenteral nutrition protocol are frequently required. The formulation of the parenteral nutrition solution has therefore to be calculated daily. The potential for computers to assist in this task has been recognised ${ }^{1}$ and the current availability of cheap microcomputers means that this aid can now be afforded by any neonatal intensive care unit. The programme described here has a number of features designed to assist in both accurate prescription and formulation. It can easily be adjusted to incorporate the preferred total parenteral nutrition protocol of an individual intensive care unit.

* Cassette tapes containing this programme suitable for use on a Sinclair ZX Spectrum (48K) are available from the author. A charge of $£ 3$ is necessary to cover expenses. (Programme listing: $£ 2$.)

\section{Materials and methods}

The programme described here is written in Sinclair BASIC language and is designed to run on a Sinclair ZX Spectrum (48K) using a ZX printer, standard cassette tape recorder, and a domestic television. The total cost of all the equipment, including a small black and white television, is less than $£ 250$. The programme can easily be modified to run on most other microcomputers. No knowledge of computers is necessary to operate the system. The programme itself is stored on magnetic tape on a standard cassette and takes approximately one and a half minutes to load into the memory of the microcomputer. Once the programme starts to run questions are displayed on the television screen in sequence; the information requested is then simply typed in on the microcomputer keyboard which resembles that of an ordinary typewriter.

Safeguards. To protect against entering values which are obviously incorrect (such as occur by putting a decimal point in the wrong place) each question will accept as answers only those values within a certain range-if the entered value is 
outside these limits a warning will appear on the screen followed by a repetition of the question. These limits are fairly wide in order to incorporate the extreme values which are occasionally required but if the entered value is at all unusual and falls outside the normal expected range a reminder of this fact will appear on the screen and only if the entered value is then confirmed will it be accepted. Furthermore, some constituents of total parenteral nutrition can be prescribed only if certain conditions are fulfilled as will be described below.

\section{Running the programme}

The following questions are automatically displayed on the screen. As soon as the first question is answered the next question appears.

LIMITS

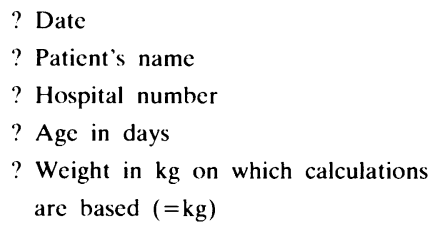

If the information necessary to answer the following questions is not available this is indicated by entering the value 99 .

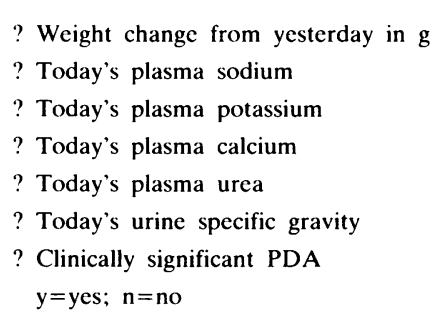

$y=$ yes; $n=$ no

LIMITS

$\mathrm{kg} \pm 10 \%$

$100-200$

1-10

$1-4$

$0-30$

$1000-1040$

In this next section a recommended value is displayed on the screen as each question is asked. There is no obligation to accept this value, though it will influence the values given to the normal range. Remember that a caution will appear on the screen if the value entered is outside the normal range. (Note, $\mathrm{R}=$ recommended value).

$\begin{array}{lll} & \begin{array}{c}\text { Normal } \\ \text { range }\end{array} & \text { LIMITS } \\ \begin{array}{lll}\text { Total fluid requirements } \\ \text { in } \mathrm{ml} / \mathrm{kg} / \mathrm{day}\end{array} & \mathrm{R} \pm 20 \% & 40-250 \\ \begin{array}{l}\text { Sodium requirements } \\ \text { in } \mathrm{mmol} / \mathrm{kg} / \mathrm{day}\end{array} & \mathrm{R} \pm 1 & 0-12\end{array}$

$$
\begin{array}{lll}
\text { ? Potassium requirements } & & \\
\text { in } \mathrm{mmol} / \mathrm{kg} / \mathrm{day} & \mathrm{R} \pm 1 & 0-10 \\
\begin{array}{l}
\text { ? Calcium requirements } \\
\text { in } \mathrm{mmol} / \mathrm{kg} / \text { day }
\end{array} & \mathrm{R} \pm 0 \cdot 5 & 0-4 \\
\begin{array}{l}
\text { ? Vamin requirements } \\
\text { in } \mathrm{ml} / \mathrm{kg} / \mathrm{day}
\end{array} & \mathrm{R} \pm 10 & 0-60
\end{array}
$$

At this point in the programme, provided that the infant is over 7 days of age, the following display appears on the screen.

\section{MAGNESIUM REQUIREMENTS}

Enter the number of the option you prefer

(1) NORMAL REQUIREMENTS $=0.16 \mathrm{nmol} / \mathrm{kg} /$ day

(2) NO MAGNESIUM (except for that in Vamin)

(3) LESS MAGNESIUM $=0.11 \mathrm{mmol} / \mathrm{kg} / \mathrm{day}$

(4) EXTRA MAGNESIUM $=0.3 \mathrm{mmol} / \mathrm{kg} / \mathrm{day}$

\section{RECOMMENDED OPTION $=1$} ENTER NUMBER?

The normal requirements equal $0 \cdot 1 \mathrm{mmol} / \mathrm{kg} / \mathrm{day}$ (which is supplied in the trace elements preparation or as extra magnesium if these are not prescribed) plus the magnesium content of any prescribed Vamin (Kabivitrum). The reduced magnesium option contains $0.05 \mathrm{mmol} / \mathrm{kg} / \mathrm{day}$ plus the magnesium content of any prescribed Vamin. As soon as the magnesium requirements have been specified the screen clears and the remaining questions are displayed in sequence.

$\begin{array}{lll} & \begin{array}{c}\text { Normal } \\ \text { range }\end{array} & \text { LIMITS } \\ \begin{array}{l}\text { ? Trace elements required } \\ \mathrm{y}=\mathrm{yes} ; \mathrm{n}=\mathrm{no}\end{array} \\ \begin{array}{l}\text { ? Dextrose concentration } \\ \text { required in } \mathrm{g} \%\end{array} \\ \begin{array}{l}\text { ? Intralipid requirements } \\ \text { in } \mathrm{g} / \mathrm{kg} / \text { day }\end{array} \\ \begin{array}{l}\text { ? Heparin required } \\ \mathrm{y}=\mathrm{yes} ; \mathrm{n}=\mathrm{no}\end{array} & 0-2 & 5-20 \\ \end{array}$

All the data necessary to formulate a solution providing these requirements is then calculated. There are a number of sources for each of the main electrolytes and this has been allowed for in the calculations (Table 1). 
Table 1 Sources of the main electrolytes

\begin{tabular}{|c|c|}
\hline Sodium & $\begin{array}{l}5 \mathrm{mmol} \text { in } 100 \mathrm{mls} \text { of } \mathrm{Vamin} \\
1 \mathrm{mmol} \text { in } 1 \mathrm{ml} \text { of } 6 \% \mathrm{NaCl}\end{array}$ \\
\hline Potassium & $\begin{array}{l}2 \mathrm{mmol} \text { in } 100 \mathrm{mls} \text { of } \mathrm{Vamin} \\
10 \mathrm{mmol} \text { in } 10 \mathrm{mls} \text { of } 8.7 \% \mathrm{k}_{2} \mathrm{HPO}_{4} \\
20 \mathrm{mmol} \text { in } 10 \mathrm{mls} \text { of } 15 \% \mathrm{KCl}\end{array}$ \\
\hline Calcium & $\begin{array}{l}2.2 \mathrm{mmol} \text { in } 10 \mathrm{mls} \text { of } 10 \% \text { calcium gluconate } \\
1.5 \mathrm{mmol} \text { in } 10 \mathrm{mls} \text { of Ped-cl }\end{array}$ \\
\hline Phosphate & $\begin{array}{l}5 \mathrm{mmol} \text { in } 10 \mathrm{mls} \text { of } 8 \cdot 7 \% \mathrm{~K}_{2} \mathrm{HPO}_{4} \\
75 \mathrm{mmol} \text { in } 1(0(X) \mathrm{mls} \text { of Ped-cl } \\
15 \mathrm{mmol} \text { in } 1(0(X) \mathrm{mls} \text { of Intralipid }\end{array}$ \\
\hline Magnesium & $\begin{array}{l}0.15 \mathrm{mmol} \text { in } 100 \mathrm{mls} \text { of Vamin glucose } \\
0.025 \mathrm{mmol} \text { in } 1 \mathrm{ml} \text { of Ped-el } \\
0.4 \mathrm{mmol} \text { in } 1 \mathrm{ml} \text { of } 10 \% \text { magnesium sulphate }\end{array}$ \\
\hline
\end{tabular}

\section{Calculation of recommended requirements}

Total daily fluids. The basic programme assumes that the total fluid intake should increase from 60 $\mathrm{ml} / \mathrm{kg} /$ day on day 1 of life to $150 \mathrm{ml} / \mathrm{kg} /$ day on day 5 and thereafter. The resulting figure will then be adjusted up or down by $30 \mathrm{ml} / \mathrm{kg} / \mathrm{day}$ (or 20 $\mathrm{ml} / \mathrm{kg} /$ day for infants under 5 days of age) on the following indications.

\section{Indications for decreasing the fluid intake} (In order of importance)

A clinically serious patent ductus arteriosus.

Urine specific gravity 1005 , or less.

Hyponatraemia ( $\mathrm{Na}$ less than $130 \mathrm{mmol} / \mathrm{l}$ ).

Weight gain from yesterday greater than $4 \%$ of today's weight.

\section{Indications for increasing the fluid intake}

(In order of importance)

Urine specific gravity greater than 1015 .

Hypernatraemia ( $\mathrm{Na}$ greater than $148 \mathrm{mmol} / \mathrm{l}$ ).

Weight loss from yesterday greater than $4 \%$ of today's weight.

This data may give conflicting evidence on the need to adjust the fluid intake. It is then interpreted in order of importance with the proviso that evidence of a clinically serious patent ductus arteriosus has the highest priority. An unusually large weight change will result in a special warning with advice on the management of fluid overload or dehydration.

Sodium. The recommended sodium intake (only after day 1 of life) is shown in Table 2 .

Potassium and calcium. The recommended potassium and calcium intakes are shown in Table 3 .
Table 2 Recommended sodium intake

\begin{tabular}{lll}
\hline $\begin{array}{l}\text { Infant's } \\
\text { weight } \\
(\mathrm{kg})\end{array}$ & $\begin{array}{l}\text { Plasma } \\
\text { concentration } \\
(\text { mmol/l) }\end{array}$ & $\begin{array}{l}\text { Recommended } \\
\text { intake } \\
(\mathrm{mmol} / \mathrm{kg} / \mathrm{day})\end{array}$ \\
\hline & $\geq 130$ & $2^{*}$ \\
$>1$ & $<130$ & 3 \\
& $<120$ & 4 \\
$\leq 1$ & $\geq 144$ & 2 \\
$\leq 130$ & $3^{*}$ \\
& $<130$ & 4 \\
\hline
\end{tabular}

In smaller infants (weight less than $2 \mathrm{~kg}$ ) who are less than 2 weeks old and who are not hypernatraemic (plasma sodium less than $145 \mathrm{mmol} / \mathrm{l}$ ) the value of the recommended sodium intake is increased by $1 \mathrm{mmol} / \mathrm{kg} /$ day.

*Recommended values if the plasma concentration is unknown.

Table 3 Recommended potassium and calcium intake

\begin{tabular}{lll}
\hline & $\begin{array}{l}\text { Plasma } \\
\text { concentration } \\
\text { (mmol/l) }\end{array}$ & $\begin{array}{l}\text { Recommended } \\
\text { intake } \\
\text { (mmol/kg/day) }\end{array}$ \\
\hline $\begin{array}{lll}\text { Potassium } \\
\text { (only after day 2) }\end{array}$ & $>6$ & 0 \\
& $5-6$ & 1 \\
Calcium & $3-5$ & $2^{*}$ \\
& $<3$ & 3 \\
& $>2.6$ & 0 \\
& $>2.2$ & 0.6 \\
& $>2.0$ & $1^{*}$ \\
& $>1.5$ & 1.5 \\
& $<1.5$ & 2 \\
\hline
\end{tabular}

*Recommended values if the plasma concentration is unknown.

Protein. This is given as Vamin glucose. If the plasma urea is greater than $10 \mathrm{mmol} / \mathrm{l}$ or if the age is less than 3 days, the operator is not invited to prescribe Vamin glucose. The programme recommends starting at $10 \mathrm{ml} / \mathrm{kg} /$ day until a maximum of $40 \mathrm{ml} / \mathrm{kg} /$ day is reached.

Magnesium. The operator is not invited + prescribe any until day 7 of life. If magnesium is requested the programme recommends that the amount given is equal to the amount contained in the trace element preparation plus the amount contained in the Vamin glucose mixture. If trace elements are not prescribed then an equivalent amount of magnesium will be included separately.

Fat. This is given as Intralipid (Kabivitrum). After day 7 of life a list of contraindications to Intralipid will automatically show on the screen. Only if the operator confirms that these are absent will an invitation to prescribe Intralipid appear.

Trace elements. Trace elements may only be prescribed if all the following conditions are met: the infant is older than 7 days, the recommended 
amount of magnesium is requested, and the calcium requested is greater than $0.6 \mathrm{mmol} / \mathrm{kg} / \mathrm{day}$. Trace elements are then given as Ped-el (Kabivitrum) in a fixed dose of $4 \mathrm{ml} / \mathrm{kg} /$ day.

The programme automatically gives phosphorus to a maximum of $1 \mathrm{mmol} / \mathrm{kg} / \mathrm{day}$. Some of this is contained in the trace element solution and in the Intralipid. Extra phosphorus in the form of $\mathrm{K}_{2} \mathrm{HPO}_{4}$ is restricted, however, if necessary to ensure that the potassium requirements are not exceeded. To avoid precipitation of calcium and phosphate, $\mathrm{K}_{2} \mathrm{HPO}_{4}$ is not given in any of the following situations: (a) if the calcium requirements are greater than $1 \mathrm{mmol} / \mathrm{kg} /$ day; (b) if the total fluid requirements are less than $120 \mathrm{ml} / \mathrm{kg} / \mathrm{day}$; (c) or if the Vamin requirements are less than $30 \mathrm{ml} / \mathrm{kg} /$ day (reducing the Vamin concentration reduces the solubility of calcium and phosphorus).

Intralipid is normally given as a $10 \%$ solution but if the requirements exceed $2 \mathrm{~g} / \mathrm{kg} / \mathrm{day}$ it is then automatically prescribed as a $20 \%$ solution. Water soluble vitamins are automatically given in the form of Solvito (Kabivitrum) (dose $0.5 \mathrm{ml} / \mathrm{kg} /$ day). Fat soluble vitamins in the form of Vitlipid (Kabivitrum) are also automatically included whenever Intralipid is given (dose $1 \mathrm{ml} / \mathrm{kg} / \mathrm{day}$ ). The concentration of dextrose used in the formulation is not necessarily the same as the concentration requested. The calculations are such that the dextrose concentration requested will be that of the completed preparation, after Vamin glucose and the various electrolyte solutions have been added. The formulation is designed to be completed by the addition of either $5 \%$ or $10 \%$ dextrose. These concentrations can be increased by the addition of $50 \%$ dextrose, enabling any particular dextrose concentration to be formulated. If heparin is requested then $1 \mathrm{U} / \mathrm{ml}$ is included in the formulation. The total volume supplied by the pharmacy is greater than the 24 hour requirements of the infant to allow for priming of the intravenous lines and minor spillage. Figures are automatically rounded off to the nearest whole number or single decimal point. The Vamin glucose/electrolyte infusion rate is, however, corrected to the nearest 0.5 $\mathrm{ml} /$ hour and the Intralipid infusion rate to the nearest $0 \cdot 1 \mathrm{ml} /$ hour. This is to facilitate the particular infusion pumps that we use.

All the information which has so far been entered; the data necessary to formulate the solutions, the infusion rates, and an analysis of the calorific value; is then printed giving a permanent record ('hardcopy').

We have now operated this system for over 9 months and applied it to 18 infants whose gestational ages ranged from 26 to 38 weeks. Partial or total parenteral nutrition was required for an average of 25 days (range 3 to 52 days) representing a total of 453 formulations. Before the introduction of this system we noted a disconcerting number of errors both in the prescription and formulation of our total parenteral nutrition solutions which seemed to relate to subsequent electrolyte disturbances. We do not believe that these problems are unique to our unit. These errors have now been effectively eliminated; electrolyte disturbances are now less frequent and rarely have an obvious iatrogenic basis.

\section{SAMPLE COMPUTER PRINTOUT \\ DATE: $\quad 13.5 .83$ \\ Patient's name: A N OTHER \\ Hospital no: 123456 \\ Age in days: 9 \\ Weight in $\mathrm{kg}$ on which calculations are based: $1.155 \mathrm{~kg}$}

TODAY'S VARIABLES

Weight changes: $\quad 35 \mathrm{gm}$

Urea: $\quad 4.5 \mathrm{mmol} / \mathrm{l}$

Sodium: $\quad 134 \mathrm{mmol} / 1$

Potassium: $\quad 3.8 \mathrm{mmol} / \mathrm{l}$

Calcium: $\quad 2 \cdot 1 \mathrm{mmol} / \mathrm{l}$

Urine specific gravity: $\quad 1010$

Significant PDA

TODAY'S REQUIREMENTS

Total fluids:

Sodium:

Potassium:

Calcium:

Vamin:

Magnesium:

Trace elements required:

Dextrose concentration:

Intralipid:

Heparin required.

\section{$120 \mathrm{ml} / \mathrm{kg} / \mathrm{day}$}

$3 \mathrm{mmol} / \mathrm{kg} /$ day

$2 \mathrm{mmol} / \mathrm{kg} /$ day

$1 \mathrm{mmol} / \mathrm{kg} /$ day

$40 \mathrm{ml} / \mathrm{kg} /$ day

$0.16 \mathrm{mmol} / \mathrm{kg} / \mathrm{day}$

$10 \%$

$2 \mathrm{gm} / \mathrm{kg} / \mathrm{day}$

\section{INSTRUCTIONS TO PHARMACY}

Total volume supplied (excluding Intralipid) $216 \mathrm{mls}$

$112 \mathrm{ml}$ of $12 \%$ dextrose (To make $12 \%$ dextrose: remove $25 \mathrm{mls}$ from $500 \mathrm{mls}$ of $10 \%$ dextrose and replace with $25 \mathrm{mls}$ of $50 \%$ dextrose).

$86 \mathrm{ml}$ of Vamin

$2.2 \mathrm{ml}$ of $6 \% \mathrm{NaCl}$

$1.7 \mathrm{ml}$ of $8.7 \% \mathrm{~K}_{2} \mathrm{HPO}_{4}$

$3.7 \mathrm{ml}$ of $10 \%$ calcium gluconate

$8.6 \mathrm{ml}$ of Ped-el

$1 \cdot 1 \mathrm{ml}$ of Solvito

$0.4 \mathrm{ml}$ of $15 \% \mathrm{KCl}$

$220 \mathrm{U}$ heparin

Total volume of intralipid supplied: $46 \mathrm{mls}$ of $10 \%$, containing $2 \cdot 3$ mls of Vitlipid

$\begin{array}{lr}\begin{array}{l}\text { Total Fluid Intake: } \\ \text { (Intralipid infusion rate } \\ 1.2 \mathrm{ml} / \mathrm{hr} \text { for } 20 \text { hours) }\end{array} & 6 \mathrm{ml} / \mathrm{hr} \\ & \\ \text { CALORIFIC CONTENT } & \\ \text { Total calorics: } & 67 \mathrm{Cal} / \mathrm{kg} \\ \text { CHO: } & 40 \mathrm{Cal} / \mathrm{kg} \\ \text { Protein: } & 9 \mathrm{Cal} / \mathrm{kg} \\ \text { Fat: } & 18 \mathrm{Cal} / \mathrm{kg}\end{array}$




\section{Discussion}

Prescribing total parenteral nutrition with the aid of a computer programme of this type offers a number of advantages over alternative systems.

(1) The low cost of microcomputers means that this technology can now be afforded by those smaller intensive care units who may benefit most from it.

(2) No claim is made that the recommended values in this programme are superior to alternative protocols and these can always be ignored. The recommended total fluid and sodium intakes, however, are an example of how a number of variables (age and weight of the infant, presence or absence of a patent ductus arteriosus, urine specific gravity, weight change, and plasma sodium) can be interpreted according to a logical but relatively complicated protocol. ${ }^{23}$ Moreover, programmes written in any version of BASIC language can easily be adjusted by anyone with a rudimentary knowledge of computer programming.

The variables used to calculate the fluid requirements could be altered. Measurements of plasma and urinary osmolality are theoretically superior to measurements of plasma sodium and urinary specific gravity. Daily osmolality measurements on very small volumes are not readily available, however, in most units. Similarly, although urinary output is an important variable, accurate total daily urinary output measurements are difficult to obtain. It is possible that an appreciable amount of unmeasured fluid is occasionally given during catheter flushing, drug administration, and endotrachael washouts. This is currently the subject of a separate study in our unit. We hope to allow for these unmeasured variables by daily weighing, if necessary by momentarily disconnecting the ventilator. If the infant's condition is particularly unstable we occasionally omit this procedure. Infants with exceptional total parenteral nutrition requirements, however, such as occur in renal failure, might well benefit from a more sophisticated analysis. The protocol presented here uses a limited number of values, readily available in most units. It is nevertheless applicable to the vast majority of infants requiring total parenteral nutrition.
(3) Recommended requirements are probably unnecessary if the prescriber is experienced in these matters. The daily requirements cannot be decided on, however, until that day's electrolyte results are available and it is frequently a junior doctor who has to interpret results and inform the pharmacy of the day's requirements. In this situation the recommended values provide a useful prompt and ensure a consistent policy within the team. The safeguards described protect against accidental errors of prescription from which even the most experienced are not immune.

(4) In this unit the pharmacy saves over one hour a day which was previously spent doing laborious calculations. This saving is particularly apparent at weekends when the pharmacy staff may have had little experience with the arithmetic of formulating total parenteral nutrition solutions. Furthermore, human errors at this point have been totally eliminated.

(5) This type of programme enables the quantity of each component of parenteral nutrition solution to be individually adjusted which can be quite difficult with protocols based upon standard solutions.

(6) The print out provides a useful permanent record which facilitates any retrospective analysis.

Finally it should be borne in mind that low cost microcomputers of this type have other potential uses in areas such as teaching and information storage and retrieval.

\section{References \\ 1 May F, Robbins G. A computer programme for parenteral nutrition and solution preparation. JPEN 1978;2:646-51. \\ 2 Lorenz JM, Kleinman LI, Kotagal UR, Reller MD. Water balance in very low-birth-weight infants: relationship to water and sodium intake and effect on outcome. $J$ Pediatr 1982;101:423-32. \\ 3 Al-Dahhan J, Haycock GB, Chantler C, Stimmler L. Sodium homeostasis in term and preterm neonates. Arch Dis Child 1983;58:335-42.}

Correspondence to Dr P MacMahon, Department of Paediatrics, Charing Cross Hospital, Fulham Palace Road, London W6 8RF.

Received 11 January 1984 